\title{
It's a Wonderful Life:Representations of the Small Town in American Movies
}

\section{Thomas Halper- Douglas Muzzio}

\section{(2) OpenEdition \\ Journals}

Electronic version

URL: https://journals.openedition.org/ejas/9398

DOI: $10.4000 /$ ejas. 9398

ISSN: 1991-9336

Publisher

European Association for American Studies

\section{Electronic reference}

Thomas Halper- Douglas Muzzio, "It's a Wonderful Life:Representations of the Small Town in American Movies", European journal of American studies [Online], 6-1 | 2011, document 8, Online since 30 December 2011, connection on 08 July 2021. URL: http://journals.openedition.org/ejas/9398 ; DOI: https://doi.org/10.4000/ejas.9398

This text was automatically generated on 8 July 2021.

Creative Commons License 


\title{
It's a Wonderful Life:Representations of the Small Town in American Movies
}

\author{
Thomas Halper- Douglas Muzzio
}

\begin{abstract}
I grew up with those [small town] people. They are the ones who do some of the hardest work in America, who grow our food, run our factories, and fight our wars. They love their country in good times and bad, and they're always proud of America. I had the privilege of living most of my

life in a small town. Sarah Palin, Address to the Republican National Convention, 2008
\end{abstract}

\section{OPENING SCENE}

1 As a youth, George Bailey cannot wait to escape tiny Bedford Falls. "I couldn't face being cooped up for the rest of my life," he tells his father. "I'm going to shake the dust from this crummy town and see the world." But forced by circumstances to give up his dream of going to college and designing skyscrapers, he remains in Bedford Falls, managing the family's small savings and loan. Not even his hope for a mere glimpse of the great, wide world is fulfilled, for just as he and his bride are about to leave on their honeymoon, he discovers a run on the savings and loan, and his sense of duty compels him to use his honeymoon money to satisfy its depositors. Over the years, George renovates an old dilapidated house and raises his family, while he continues running the savings and loan.

2 A sense of failure, however, continues to haunt him, and when he sees his savings and loan on the verge of collapse, George prepares to end it all and jump off the town bridge. At this point, his guardian angel intervenes to show him what Bedford Falls 
would look like, had he never lived. In a powerful, frightening, nightmare sequence, George wanders through the town, now named Pottersville (after "the richest and meanest man in the county," a skinflint provincial villain). It is a seedy, garish caricature of a small town stereotype of city life, replete with burlesque houses, nightclubs with neon signs advertising good times, and drunks and prostitutes walking the streets. The angel's urban counterfactual works, and George abandons his thoughts of suicide.

3 The film closes with a Christmas eve celebration of community, in which all the little people and "garlic-eaters" George had helped over the years (with what we might now term "subprime mortgages") give him the money he needs to save his imperiled savings and loan. "He's surprised to learn that he was not a failure," explained the film's director, George Capra, "that he fitted into the scheme of life and actually contributed much to the happiness of several people" (Capra, quoted in Basinger 44).

It's a Wonderful Life, the most revered movie about American small towns, is typically hailed as a paen to the virtues and rewards of small town life in a golden era. And it is true that if it raises important questions about small town life and American capitalism, it seems, finally, to respond with the fatuous bleat that the spontaneous goodness inherent in small town folks is the great problem solver. George reaps spiritual rewards - and is ultimately redeemed - by putting the interests of his family and community before his own. This is the small town way.

But this upbeat narrative, the movie also reminds us, is incomplete. For much of the film, after all, George feels depressed, trapped, so angry that he lashes out at his saintly wife and adorable children, literally suicidal. And had there been no George - and many small towns presumably lack such a savior -- Bedford Falls could hardly have offered a wonderful life. Indeed, behind every Bedford Falls, the film reminds us, lurks a potential Pottersville.

6 This essay discusses the movies' representations of small town life, highlighting the nation's ambivalent and evolving beliefs and attitudes. The movies selected for discussion are all American films - foreign and documentary movies are excluded - and are considered to be significant commercially or critically or because they typified their genre. Commercial success is an indicator that the movies resonated widely with the public; critical acclaim may point at exerting influence on future movies. The movies selected are also "small town-centered," that is, the small town actively participates in shaping character and plot, rather than "small town-set," where the substitution of another background locale would alter only the details. There is an element of subjectivity in this, but these criteria are standard in the field (e.g., Sanders; Doherty; Christopher).

\section{THE SCRIPT}

7 A century ago, Georg Simmel warned that the

deepest problems of modern life flew from the attempt of the individual to maintain the independence and individuality of his existence against the sovereign power of society, against the weight of the historical heritage and the external culture and technique of life (Simmel 409).

8 These problems, Simmel believed, are most oppressive and intractable in the great metropolises, where cliché metaphors hint at the plight of the individual: from tall 
buildings, persons seem like ants; packed in subways, they resemble canned sardines; as they hustle off to work, they join in the rat race. The sheer number and variety of people that mark the metropolis' advantages - economies of scale, wide choice, low transaction costs - overwhelm the individual, depriving him or her of the independence and individuality that give meaning to life. ${ }^{11}$ The adage that big cities atomize experiences, moreover, seems amplified by a ubiquitous technology, where disconnectedness is epitomized by IPods and Kindles that isolate the users' experiences from the profusion of experiences surrounding them. Technology's response to this atomization - the creation of innumerable niches (Facebook, blogs) - appears only to add velocity to these powerful centrifugal forces.

The answer, it used to be said, is the small town, where we find ourselves not in an immense sprawl inhabited by strangers but in a compact area peopled with family, friends, and acquaintances. As if taking their cue from Kant (himself a small town boy from Konigsberg), small town people treat each other not only as means but also as ends. They see us, that is, not as ciphers occupying narrow roles but as whole persons, and the warmth and friendliness this generates nurtures us, and imbues the quotidian rituals and tasks of daily life with a communitarian spirit that deepens and enriches life. Who would not want to be a neighbor of Norman Rockwell? So potent is this notion that even today the authenticity implied by small town life may prove a major political asset, witness one President's pledge never to tell us a lie (Jimmy Carter from Plains, Georgia), another's observation that it was morning in America (Ronald Reagan from Dixon, Illinois), and a third's insistence that he feels our pain (Bill Clinton from Hope, Arkansas). There is a permanence about the small town of our imagination, in contrast to the merciless, unceasing change of big cities, and as a fictional small town factory owner put it, big city folks

[d]on't know what houses are or what living is. They forget that money doesn't buy everything. . . . They don't understand pride of craftsmanship or pride in a community. The longer you live here, the more you know that there's nothing like a small town for happiness (Marquand 317).

The metropolis may promise more money and glitz and more trendiness and excitement, but this is merely the sizzle. If you want the steak, try the small town.

Yet there are many who prefer the sizzle. Simmel's good friend, Max Weber, for example, saw the impersonality of the metropolis as offering individuals greater opportunity to express their individuality (Weber). One can drown in a sea of small town friends and acquaintances, he knew, and how intrusive and nosy they may be and how oppressive their pressure to be like them. Impersonality may seem cold and its rules and enforcers controlling, but the informal controls of small communities, exercised via gossip, avoidance, ostracism, and (most powerfully) internalization, may be much harder to escape. For group identities in small towns tend to rather comprehensive. Where a big city worker, for example, might find him/herself identifying with a variety of groups, economic, ethnic, religious, and so on, a small town worker, in a much more homogeneous setting, might discover that his/her groups overlapped so heavily that he/she might experience but one group identification. In place of the countervailing, limited group identities - echoing the Madisonian factions of an extended republic -- would be a single, amorphous identity that encompassed the entire personality. Some individuals, like fish in water, may take this environment for granted, never contemplating resisting prevailing norms and 
values. Others, though, might flee this claustrophobic setting for the tranquility of urban anonymity. ${ }^{2}$

The social pressure to conform may also have larger consequences for the community, if it takes the form of nostalgia for a romanticized past that may become a barrier to adaptation and change, a reason to disdain what is new and different, an excuse to stick to the tried and true. All of which may not only rob life of its vigor and sparkle, but handicap the community as it competes with more forward looking communities.

The metropolis threatens the individual, it turns out, but so does the small town.

This ambivalence is hardly of the movies' invention. American poets and writers, following in the tradition of Oliver Goldsmith's "The Deserted Village" (1894/1770), had long celebrated the small town as an idyllic refuge, and the primacy of agriculture was routinely celebrated, as in William Jennings Bryan's declaration in his famous Cross of Gold speech: "Burn down your cities and leave your farms, and your cities will spring up as if by magic; but destroy our farms and the grass will grow in the streets of every city in the country" (Bryan I, 248-49). By this time, however, urbanization was thundering onward, and late 19th and early 20th century writers were often sharply critical. These realists immersed themselves in the everyday, and in works like Hamlin Garland's Main Travelled Roads (1899), Edgar Lee Masters' Spoon River Anthology (1962/1915), and William Dean Howell's A Modern Instance (1923) displayed the grievous faults of provincial life. Movies were capable of revealing this ambivalence with great, if usually inadvertent, force.

\section{THE BEGINNINGS}

15 Once upon a time, America was a place of small towns, villages, and farms. When Jefferson railed against the pestilential character of big cities (Jefferson IV, 86), the nation had none. But in time big cities emerged, holding out the promise of opportunity: opportunity for a better job, for a more interesting life, for fun and romance and excitement. The promise of opportunity drew people from all over - from Europe and from the small towns and countrysides of America. Meanwhile, those left behind in these small towns were often subject to "an unconscious absorption of many of the standard myths about small town complacency, neighborliness, godliness, stupidity, provincialism, loyalties, unity, freshness" (Lyford 1964: 129), accepting others' stereotypes as defining their situation. They had learned - from McGuffey's Readers, families, and friends - that small towns were morally superior to big cities, but they resented what they took to be the city's unfair advantages, and often succumbed to a small town inferiority complex, complete with psychic chips on their shoulders. At the same time, those who abandoned their small towns for big cities many times discovered that what appeared from a distance to be opportunities seemed on arrival more like hardships. They might remain in the city, struggling, but their memories of their small town roots were apt to take on a rosy, sentimental glow. For these reasons, even as big cities were flooded with new residents, the venerable Jeffersonian stereotype did not fade away. The city continued to be widely seen as dangerous, unfriendly, an occasion of sin. The small town, as the chief alternative to the city, was a refuge: safe, wholesome, upright. Its very smallness ensured that it existed on a human scale, and thus appeared fitting and natural. 

underscore the observation that all small towns are not the same. Like snowflakes, each is unique. Thus, even the readily recognizable categories are numerous. There are agricultural centers (Keosaqua, Iowa), county seats that serve as political/legal centers (Black River Falls, Wisconsin), industrial centers (Kohler, Wisconsin), recreational centers (Wildwood, New Jersey), college towns (Canton, New York), art centers (Provincetown, Massachusetts), retirement communities (Mount Airy, North Carolina), religious communities (Monsey, New York), and even state capitals (Pierre, South Dakota). There are Southern towns with main squares (Shelby, Tennessee) and Midwestern towns with string-straight Main Streets (West Bend, Iowa); there are rich towns (Litchfield, Connecticut), poor towns (Samson, Alabama), and in-between towns (Pompton Plains, New Jersey); there are old towns (Warren, Connecticut), new towns (Riverside, Georgia), and middle aged towns (New Athens, Illinois). Enormous diversity is not exactly unexpected.

When movies became popular, America was still a nation of small towns. Movies, however, were emphatically an urban phenomenon, made in cities (first New York and then Los Angeles) for city folk (chiefly, the working class). Notwithstanding this urban dominance, most pre-World War I movies focused on small towns (Griffith, Mayer, and Bowser 110), and these towns were overwhelmingly described as friendly places, governed by honesty, fair play, and helpfulness. They epitomized what was best in the country. They embodied America's soul.

Subgenres developed, for example, featuring small town girls seduced and abandoned by worldly big city men - girls who usually return to the bosom of their families, renounce their evil ways, and become wholesome again (e.g., The Miller's Daughter [1905], A Country Girl's Peril [1909]). In a twist on this tale, True Heart Susie (1919), a Lillian Gish vehicle directed by D.W. Griffith, follows a classic small town couple, who (according to a title) "don't know what poor, simple idiots they are." She sells her adored pet cow, so he can go off to divinity school; while there, he falls for a "painted and powdered" city woman; she eventually gets him back, though by this time we wonder whether he is worth the effort. Even in the more permissive roaring '20s, this subgenre continued on (Way Down East [1920], Gentle Julia [1923], The Boy Friend [1926], Why Girls Go Back Home [1926], Broadway Madness [1927]).

Though silent movies generally idealized small towns, they were not entirely silent as to their faults. These faults, too, were usually of the stereotypical kind: hypocrisy (The Town Scandal [1923]), conformity (The Conquest of Canaan [1921]), gossip (Miss Lulu Bett [1921], narrow mindedness (Way Down East [1920]), and snobbery (Keeping up with Lizzie [1921]). Negative depictions, however, were not common. Wise parents, friendly neighbors, benevolent doctors - these are the typical inhabitants of small town silent movies.

What the '20s movies never produced was a thorough going critique of the small town as preoccupied with social status. It was not that this idea was unknown, for it preoccupied perhaps the most prominent novelist of the day, Sinclair Lewis. In the best-selling Main Street (1920) and Babbitt (1922), Lewis satirized the small town commercial way of life and its stultifying web of trivial relationships. "I've never done a single thing I've wanted to in my whole life!" Babbitt admits to his son at the end of the book. "I don't know's I've accomplished anything except just get along." Thus did the celebrated practical ethos of the small town, so contemptuous of the abstract 
intellectual ethos of the big city, lead to empty, wasted lives - and become, in a devastating word, impractical. A few years later, the Lynds famously reported on the dominance of the practical ethos in Middletown (1929). Still, so seductive was the image of the small town as wholesome refuge that it persisted despite immense changes changes in society (the Great Depression) and changes in the movies (the advent of talkies).

\section{THE DEPRESSION AND AFTER}

The Depression, among other things, was a brutal attack on prevailing verities: the inevitability of progress, America as a land of material abundance, hard work and honest-dealing as a path to the good life. Its causes defied understanding - essentially, the same combination of land, labor and capital had produced a boom only a few years earlier - and as year followed year its cure remained frustratingly out of reach. Small towns suffered grievously during the Depression, generally more than cities. Yet into this bleak picture, Hollywood plunked the small town as the nation's cheerful haven from the gloom, particularly in the extraordinarily successful sixteen film Andy Hardy series (1937-1946). In Andy's tidy town, Carvel, there is no poverty, father knows best, and the great question of the day is whether the perky teenagers will be able to put on a song and dance show. Carvel was utopia - neighborly, fair, decent, bursting with generalized good will. A special Academy Award was given to M-G-M in 1942 "for its achievement in representing the American Way of Life," the Hardy films grossed a spectacular \$73 million, and Mickey Rooney, who played Andy, became the nation's top box office attraction. Similar themes were struck with Henry Aldrich (eleven films from 1939-1944), Blondie (twenty-eight films from 1938-1950), and Dr. Kildare (fifteen films from 1938-1947). The small towns of these serials, in a sense, resembled "island communities," which looked inward to shield themselves from the troubles of the larger world, and existed quite apart from the larger socioeconomic context (Weibe 88).

During this period, small town films often either brought the cynical city dweller to the country to have his faith in America restored (Boys Town [1938]) or brought the townsfolk to the city to teach its inhabitants a moral lesson (Mr. Deeds Goes to Town [1936]). Boys Town, echoing a social view going back to the mid-19th century's "placing out" system pioneered by Charles Loring Brace of the Children's Aid Society (Brace), argued that since city slums cause delinquency, the answer is to move the boys to the country - in this case, to an orphanage in Nebraska. Mr. Deeds was Longfellow Deeds, an eccentric small town New Englander of granite integrity, who inherits \$20 million, and to the consternation of crooked city slickers (who think him a "yokel" and a "country lout") decides to give it to the poor and return to his town. Along the way, a cute newspaperwoman tries to manipulate him, but is finally undone and redeemed by his rugged and intelligent rectitude. ("He's got goodness," she exclaims. "Know what this is? ... We've forgotten. We're too busy being smart-alecky. Too busy in a crazy competition for nothing.") Deeds stands sturdily in the long tradition of Young Men from the Provinces derided for unworldly virtue mistaken for naiveté or stupidity. As a Depression fable, the movie resonated powerfully.

23 Four Daughters (1938), a great commercial success, took a different tack. Four small town daughters and their lovable father, all preoccupied by the prospect of the girls' spinsterhood, encounter a pair of big city musicians. One is "the nicest thing that's 
come into our house since the electric percolator," but the other is surly, cynical, full of self pity. Eventually, the surly one, ashamed because his failures are interfering with the relationship of the nice one and a daughter, runs his car off a cliff. Contact with a small town could not save him, but the fault is not the town's but his - and after his death, the other characters live happily ever after. Several major movies sought to portray small towns with more ambivalence, acknowledging their virtues but also highlighting the community's conflict with assertive individualism, and even touching on the always delicate matter of socioeconomic class. Dr. Bull (1933), directed by John Ford, follows a folksy New England doctor (played by the quintessentially folksy Will Rogers). Unpretentious and old fashioned, he gruffly "prescribes common sense," and is idiosyncratic and suspicious of new fangled technologies. The local lumber mill pollutes the town's drinking supply, leading to a typhoid epidemic; the local politicos, fearful that this might ruin the summer tourist season, oppose the doctor's call to boil drinking water and institute mass inoculations. At a town meeting, he announces, "Right here and now, I quit," his integrity intact. In a final twist, he becomes famous for curing a patient of paralysis. Is Dr. Bull hostile to small towns? New Winton, Connecticut's power structure is surely greedy and corrupt, the routines of daily life cyclical and boring, and the gossip mongers obnoxious and intrusive; even the democratic town meeting does not produce the right result. Yet the big city is not the answer - Bull disapproves of the big city doctor, and his esoteric scientific knowledge and fancy car - and so Bull, when he leaves, leaves for another small town.

More successful commercially and artistically was Alice Adams (1935), drawn from Booth Tarkington's Pulitzer Prize winning novel (1921). Alice, twenty-two and pretty, comes from a poor, small town family, but longs to be swept away by "somebody new, who is tall and dark and romantic" and can offer her a comfortable and exciting life. Hoping to ensnare the socially prominent Arthur Russell, she pretends to be rich and sophisticated, first at a dance and then at a calamitous family dinner. Arthur learns of this pretense, but by then he has fallen for her, as she had for him, and the movie closes with their embrace. (In the more tangy novel, Alice does not catch Prince Charming, but rather ends up registering at a secretarial school.) The small town of South Renford, Indiana, is riven with class fissures, and Alice, snobbier than the rich, seems driven by class envy. Yet the movie is not anti-rich: the unattractive characters (Alice's whiney mother, weak father, and nasty brother) are usually poor, and the attractive characters (noble Arthur and Alice's father's forgiving boss) are usually rich. Like Dr. Bull, Alice is an individualist, who does not fit well in a confining small town. But unlike him, she is no model of integrity nor is she concerned about the welfare of the community. Instead, she seems a romantic narcissist, who might well have encountered the same difficulties had she lived in a big city.

Brutally hostile to small towns was Fury (1936), directed by Fritz Lang. A big city man on his way to see his fiancée is arrested in Strand, Illinois on suspicion of kidnapping. Though there is little evidence against him, the townsfolk gradually become irrationally convinced of his guilt and, in a mob frenzy, they set fire to the jail, joyfully watch it burn, and finally dynamite it, believing the prisoner has perished. He escapes, though, and it develops that there is a newsreel of the event that can be used to try the perpetrators. Traumatized, the man demands that the townsfolk be tried and given "a legal death." His fiancée, however, is horrified by his thirst for revenge, but though he 
relents somewhat, he is left totally disillusioned by his experience. He hopes that the townsfolk have learned from their terrible behavior, but they all seem to believe that, as one woman put it, "it would be a blessing if the community would forget what happened. It just leaves a bad taste." None of the established authorities comes off well, not the business or political leaders or the police or the press, all of whom are indifferent to the injustice. The man and his fiancée get together at the end, but the moral failure of the townsfolk and their leaders and the man's residual drive for revenge "leave a bad taste." The much praised small town sense of togetherness, it seems, may spark an anger at outsiders that knows no limits, as the standard confines of law, habit, and convention evaporate in a flash - and this togetherness may also stifle any impulse of remorse.

In its animus, Fury was probably unique. W.C. Fields poked devilish fun at small town gullibility in The Bank Dick (1940) and Never Give a Sucker an Even Break (1941), but these comedies had none of Fury's relentless bitterness. Much more typical (and popular) were Young Mr. Lincoln (1939) and Abe Lincoln in Illinois (1940), hagiographies of the nation's most venerated small town icon. Proverbially honest, down-to-earth charming, a self-made man who still cherishes his roots, Lincoln is the perfect small town product: the uncommon common man.

There was no more powerful celebration of the small town as the embodiment of the best in American life, however, than Our Town (1940), whose screenplay by Thornton Wilder followed his Pulitzer Prize winning play (1939). Life in the quaint town of Grover's Corners, New Hampshire (pop. 2642) is shown in three periods - 1901, 1904, and 1913 - through the earthy narration of the town druggist, who profiles the lives of its representative citizens on a day of no particular significance. The fences are white picket, the streets are tree lined, the porches have swings. Apart from a brief allusion to "foreign workers" who live "across the tracks," there are no class differences everyone is middle class in attitude and material possessions - and everyone is caring and humane. The Aaron Copland music underscores the warm rhythms of the community.

Yet Grover's Corners is no Hallmark card. George and Emily are followed as they grow from childhood playmates to romantic couple to blissful husband and wife. Then, abruptly, Emily dies in childbirth, George is devastated, and from beyond the grave Emily pleads to return to earth, if only for a single day (her twelfth birthday) - a wish that is granted to her regret, as she grieves over how the living thoughtlessly squander their brief time on earth. "Do any human beings ever realize life while they live it?" she asks. How tragic that we seem constituted to pass our days mindless of our inestimable gift of life (though could we ever accomplish anything if always bedazzled by the miracle of being alive?). Small towns cannot immunize their residents to the tragedies of life nor guarantee that we truly appreciate its value, but they can go far to ameliorate Simmel's problem of maintaining independence and individuality.

What was absent in most Depression films about small towns was the Depression, either because the film was set in another era or because the town portrayed was oddly untouched by widespread hardship and unaware of its prevalence elsewhere. This was emphatically not what Sherwood Anderson, one of the great chroniclers of small town life, found from his travels in the Midwest and South. Yet Anderson, a radical, conceded that he detected no revolutionary anger, but instead "a crisis of belief." The "American theory of life" that ambition would lead to upward mobility had collapsed, leaving a 
void filled by confusion, puzzlement, and despair. Over and over, he heard men say, "I failed. I failed. It's my own fault" (Anderson 1935). Nor did small town movies feature the Hopperesque storefronts of Walker Evans (Agee and Evans 1941) or other iconic representations of social failure and despair. Nor did these movies even share the view of Middletown in Transition (1937), where the Lynds found that the residents of Muncie tended to interpret the Depression as an "interruption" to be "waited out," and not an emergency indicating radical, systematic failure. Thus, in bypassing the Depression, most small town movies may be called escapist just as surely as the Indiana Jones or Star Trek adventures of another time.

31 With the passing of the Depression, there was less need of the small town as refuge, and so harsher views came to be presented with greater frequency. The Magnificent Ambersons (1942), Orson Welles' follow-up to his landmark Citizen Kane (1941), is a somber study of the decline of the leading family in a small Indiana town in the late 19th century. Based on the Pulitzer Prize winning novel by Booth Tarkington (1918), the movie tells the story of a beautiful heiress, Isabel Amberson, and her family. Isabel rejects fun loving Eugene in favor of stuffy, conventional Wilbur because Eugene had gotten drunk and embarrassed her at a party. As time passes, Wilbur dies and their son, George, "spoiled enough for a whole carload," grows up self-centered, entirely unproductive, and fixated on his mother. At the same time, the family fortune is dissipated, and Eugene, by now prosperous and a widower himself, attempts to reunite with Isabel. Disgusted by their second chance romance, George manipulates his mother into rejecting Eugene, ruining her opportunity for happiness. Meanwhile, the Ambersons' beloved town is changing and they hardly notice it, and therefore fail to grasp that the changes threaten the value of their properties on which their status, power, and comforts rest. So passive is the family that it barely qualifies as spectators at its own decline. Subtly and indirectly, the movie explores the consequences of the socioeconomic forces that displace the old aristocracy with the new ambitious bourgeoisie in the name of progress. Though Welles charged that the studio's editing destroyed his work, the movie manages to convey the sometimes stifling quality of small town life: the prying chatter, the small minded rejection of even petty nonconformity, the connection of money with social status and individual work, the injustices of class in a cramped setting. In the end, the downfall of the Ambersons coincides with the town's (in the words of the narrator) "spreading and darkening into a city."

The same year saw the release of Kings Row (1942), also about a Midwestern small town around the turn of the century. The film opens with a road sign reading, "Kings Row. A good town to live in, and a good place to raise your children." The irony is heavy and unmistakable: Kings Row, a town of some 8,000, is a place of fear, hypocrisy, homicide, suicide, incest, euthanasia and insanity, and children seem its chief victims. Duplicity and paranoia feast on intrusiveness masquerading as friendship; no one can be trusted, not even one's family. The traditional ideals of health, harmony, and community are trumped by the actuality of neurosis and psychosis. Nor is money the answer: nearly all the characters are from the upper classes, and one is insane, another dies from cancer, a third is poisoned by her father (who then shoots himself), a fourth is a sadistic surgeon, and a fifth is a crooked banker. Kings Row belongs to the genre of the mean spirited small town, like the vastly superior novels Winesburg, Ohio (1919) by Sherwood Anderson and An American Tragedy (1925) by Theodore Dreiser. 

adapted by William Saroyan from his best-selling novel set in tiny Ithaca, California. His father recently dead and his brother off to war, 15-year old Homer Macauley takes a job as messenger boy at the telegraph office. His coming of age is detailed in a series of vignettes involving his straight talking (but kind) boss, his alcoholic (but sweet) telegraph operator, and assorted other characters. There are elements of sadness - he delivers a telegram to a Mexican woman whose son has died, he learns of his brother's death at the movie's conclusion, and his dead father narrates the story from beyond the grave - but the general impression is one of uplift. The town is so pretty, all the people are so friendly and good, so eager to share what they have and help those in need, so much in love with their country and willing to sacrifice for it - this is an idealized America emphatically worth fighting for.

the war ended, a far more nuanced view was presented in The Best Years of Our Lives (1946), a huge commercial and artistic success, which won eight Academy Awards, including best picture. Set in a Midwestern town adjusting to the end of World War II, the film focuses on three very different GIs returning home: a slum raised soda jerk who comes home a captain to his adulterous wife, a bank president who comes home a sergeant to his perfect and beautiful family, and a middle class boy who comes home a sailor with both hands destroyed to his girl friend. Notwithstanding their differences, all three have in common years away from home at war and serious anxiety about resuming old relationships and reconstructing their lives. What they find is that people, for the most part, want to do the right thing, but circumstances, habit, or ignorance often overwhelm these efforts. Small town bromides, even when honestly believed, may be cruelly insufficient. In the end, the three struggling veterans find jobs where they hope to build their future, but their success is by no means assured.

In sum, in the pre-television era of movie dominance, the myth of the small town as secure, warmly enveloping and quintessentially American remained the dominant theme. As a character in a novel set in a postwar small town declared, its residents are

living smack-dab in the middle of the greatest country in the world. [...]. We had just beaten the Germans and the Japanese in a fair fight.[...] We had John Wayne, Betty Grable, Mickey Mouse [...] Ivory Snow, oleomargerine and the atomic bomb (Flagg 2002)!

At the same time, however, a minor theme stressing intolerance, narrow mindedness and provincialism was also sounded. The positive stereotype was louder, but the negative did not go unheard.

\section{THE LAST HALF CENTURY}

In the 1950s, the negative minor theme became more pronounced, and in addition to the standard complaints, it was now sometimes alleged that small town life could be searingly lonely. In The Member of the Wedding (1953), taken from Carson McCullers' play (1946), a twelve year old tomboy in a small Georgia town was, in her own words, "a member of nothing in the world." Her mother is dead, her father shows no interest in her, her peers avoid her - she has only the family's African American housekeeper and a nearby cousin, who is also very lonely and who eventually dies. After her brother's wedding, in a desperate effort to break out of her isolation, she packs a valise so that she can join the couple on their honeymoon; her father then takes her, screaming, from

European journal of American studies, 6-1 | 2011 
the car. When the housekeeper quietly leaves town, the girl begins to try to make friends by speaking to a new girl in the neighborhood and by dressing more girlishly. Yet if this suggests that the point is that the road to happiness is conformity, the movie really argues the reverse: that communities oppress those who are different by denying them membership, and that small communities may be the most oppressive because they offer so few alternatives.

Loneliness was also a powerful element in Picnic (1955) (based on William Inge's Pulitzer Prize winning play [1953]), particularly in its sexual manifestations. Picnic sees a handsome drifter arriving at a small town to start anew, and encountering a number of sexually repressed women, who regard him as the answer to their prayers. At the end, he and the prettiest girl each leave town to meet at far off Tulsa. Will they actually get together? Will their union prove happy and lasting? The implication is yes, but the pervasive loneliness and depression that hang over the first portion of the movie necessarily raises doubts.

Conformity and its resulting repression and hypocrisy lay at the core of Peyton Place (1957), based on a hugely popular best seller by Grace Metalious (1956). Peyton Place is a postcard pretty New Hampshire town, marred by guilt and shame, hostile rumors and sanctimonious duplicity. A rigidly respectable widow is in fact an unmarried mother; a war hero's medals are fakes; another character rapes his stepdaughter. There are two kinds of people, Metalious has a character say:

Those who manufactured and maintained tedious and expensive shells, and those who did not. Those who did lived in constant terror lest the shells of their own making crack open to display the weakness that was underneath, and those who did not were either crushed or toughened.

Togetherness, the movie instructs, may hobble individual growth and fulfillment (especially, sexually).

41 A few years later, Splendor in the Grass (1961), directed by Elia Kazan from a screenplay by William Inge, also explored the marketable issue of sexual repression in a small town, this time in Kansas in the 1920s. The Stampers, with wealth and position from the family oil business, are dominated by the father, Ace; the Loomises, who own a modest grocery, are dominated by Mrs. Loomis. The families intersect when Ace's son, Bud, untainted by the drive for money, falls for the Loomises' virginal daughter, Deanie. Mrs. Loomis is determined that Deanie marry well, but warns her that having sex with Bud will cost her his respect (and that, in any case, "A woman doesn't enjoy those things the way a man does"). Ace pins all his hopes on Bud - he has written off his daughter, who fled their "God-forsaken town," flunked out of college, and had an abortion - and worries that he not do "anything you'll be sorry for" with Deanie. Scene after scene depicts the couple's sexual frustration. Eventually, Deanie collapses psychologically and requires institutionalization, Bud marries someone else, Ace's daughter is killed in an auto accident, and Ace himself commits suicide after business reverses. At the end Bud and Deanie meet again, each by this time freed from the romanticism that blighted their earlier years. Small town social pressure, the film teaches, may not only generate conformity in minor behaviors, but may also be internalized and do battle with the most fundamental of social and biological urges. Sexual repression was also the theme in a pair of movies made from Tennessee Williams' plays, Summer and Smoke (1961) and Sweet Bird of Youth (1962). 

antithesis of Gone with the Wind, it is one of the last movies to retain the old South orientation, complete with a groveling Stepin Fetchit, an unappetizing Yankee prosecutor, and the strains of My Old Kentucky Home. Set in small town Kentucky in 1905, the film follows salt-of-the-earth Judge William Pittman Priest, whose integrity and compassion threaten to defeat his reelection efforts by leading him to say and do politically unpopular things. Of course, he wins reelection, thwarting a lynching and joining a funeral march for a prostitute - in the process, engulfing the town in a sweetness that tosses together Confederate and Union veterans, prostitutes and upright merchants, would-be lynchers and a black church. Ford unaccountably considered this perhaps the favorite of all his movies.

46 prominently in To Kill a Mockingbird (1962), adapted from Harper Lee's Pulitzer Prize winning best seller (1960) by Horton Foote. Here, in 1932 a respected lawyer and pillar of the Maycomb, Alabama establishment defends a black man charged with raping a white woman, the critical scenes taking place within a prototypical Southern court house. In denouncing the racism damaging his client, the lawyer is viewed by some of his neighbors as a traitor; despite his best efforts the man is (apparently unjustly) convicted; seeking to escape, he is shot by the police. Yet the film's tone is hopeful in a naïve sort of way: the Ku Klux Klan is described as "a political organization more than anything else," whose members are so craven that when they gathered in front of a 
house owned by a Jewish man, "Sam made 'em so ashamed of themselves they went away." Even in a benighted backwater, evil lacks conviction, and persons of decency with a sense of responsibility and fair play will stand up for what is right. Following in this spirit, In the Heat of the Night (1967), set thirty years later, brings a slick black detective from Philadelphia down to stereotypically peckerwood Sparta, Mississippi to help the local redneck sheriff solve a murder. At odds at the beginning, they ultimately come to like and respect each other, and work together to solve the crime. A small town can bring out good will even among the most unlikely adversaries.

Yet the quintessential small town movie of the early ' 60 s - before the Vietnam War had worked its corrosive cynicism - was The Music Man (1962), a friendly musical satire of life in provincial Mason City, Iowa (renamed River City) in the 1920s. It is a strikingly similar, though far gentler, indictment of the smug and complacent gullibilities found in Twain's Huckleberry Finn, with its interminable self-congratulation, bubbling outrage at outsiders, and relentless promotion of imagined small town virtues. Its theme of a newcomer gulling small towners was hardly new. Elmer Gantry (1960), based on Sinclair Lewis' novel about a cynical evangelist (1927), and The Rainmaker (1956), a tale of a charlatan who promises to bring rain to a drought stricken rural area, were contemporary movies on the same theme, and silent film examples include The Flirt (1922), Dollar Devils (1923), and The Confidence Man (1924). The Music Man, however, was far more popular than these.

"Professor" Henry Hill, a silver-tongued con man, drifts into town and persuades its residents that they need a fine, big marching band, all for his own financial enrichment. Along the way, he gives them faith and brings them fun (when Hill asks, "What do you folks do for excitement?" the response is, "Mind our business"). Yet when they discover that they have been bamboozled, they want to tar and feather him. The sting of the attack is blunted at the culminating town meeting, however, where the small town values of decency and community are reaffirmed.

By the 1970s, the small town, apparently battered by repeated assaults - shopping centers, interstate highways, declining farm populations, and so forth - no longer seemed a refuge or even a butt of familiar jokes. Rather, in the movies, the small town now was frequently an occasion of pity. The Last Picture Show (1971) discards, as if it were yesterday's newspaper, the vision of a harmonious small town with a bright tomorrow. (More recently, this theme was echoed in Last Night at the Lobster [2007], a novel depicting the closing of a Red Lobster restaurant in down-at-the-heels New Britain, Connecticut.) Unlike Grover's Corners, Anarene, Texas in 1951 is bleak and rundown, with a future threatening to be even drearier than the present. "Everything is flat and empty here," complains the beauty queen daughter of the town's richest family, "and there's nothing to do." "I'm sick of this town," says another of the movie's young characters, and the audience can only agree. With the closing of Anarene's only movie theater, there are no longer even any Hollywood manufactured dreams to sustain the few remaining residents. Here, the film's director, Peter Bogdanovich, a movie fan of legendary proportions,seems to be saying, "Life without movies means life without sustaining hope and vision." Television, the movies' enemy, becomes Anarene's enemy, too; the town's adults are anesthetized by TV, allowing their communal bonds to fade away. There is plenty of sex and attempted sex and lots of playful joshing, but the undercurrent is one of passivity and pessimism, for it is obvious to all that Anarene has no future. 

sunrise in 1962 in Modesto, California against a background of cruising cars, drive-ins, hamburger stands and ' 50 s rock ' $n$ ' roll (plus some early '60s Beach Boys). The entire decade of the 1950s as well as Hollywood's representation of that period is acted out in a small town setting, focusing on teenagers on the eve of adulthood. Three local boys contemplate leaving "this turkey town" for college, but the movie takes no strong position on the goodness or badness of the town. One of the boys, though, knows that his future is in the city - the movie implies that the nation's future is also in the city but he is reluctant to leave his hometown, realizing that he will never be able to recreate its intimate friendships. If he lived in Anarene, of course, his choice would be easy. But growing up, American Graffiti suggests, can force us into painful tradeoffs.

51 The question of what to do following high school graduation was also the focus of Breaking Away (1979), which takes place in "Bloomington - Home of Indiana University." Four working class boys, looked down on by college boys, feel like outsiders in their own hometown. Three of them are resigned to their status, but the fourth aims higher, as symbolized by his entry in a big bicycle race. Preparation is difficult and painful and the chance of success appears remote, but he perseveres and triumphs. Small towns, even small college towns, reek of class conflict, and yet they are sufficiently open and meritocratic to allow worthies without economic advantages to prevail.

Even more highly praised was Deer Slayer (1979), set alternatively in Clairton, Pennsylvania and wartime Vietnam. The film follows three Russian-American steelworkers, but in place of the traditional warm ethnic ambience is pervasive dysfunction: heavy drinking, woman beating, cruelty. Clairton, ugly and forlorn, is a place far from Andy Hardy's Carvel. It is also far from the locus of political power. As a character in a recent novel observed,

The nation went to war. The small towns of America played no role in this except to supply the votes and the armies. Really, the decisions were made elsewhere by others ... They were the authorities. They held the high card. I thought of them as Homer thought of the Fates, entitled to make any decree they wished (Just 215).

Other popular films during this period - like Jaws (1975) and Carrie (1976) - announced that beneath the small town's bland veneer, strange and nasty things were going on.

Norma Rae (1979), which won an Oscar for its star and was nominated for best picture, revisits the theme of an outsider shaking up a small town set in its ways - but with a twist. The outsider is a stereotypically aggressive, intellectual New York Jew; the twist is that he is not there to reveal their foibles (as in Music Man) or their prejudices (as in In the Heat of the Night), but instead to help them by organizing a labor union in their textile mill. The battle, which involves anti-Semitism as well as economic hopes and fears, allies the New Yorker with a spunky, local single mother, Norma Rae. Norma Rae is not the standard movie heroine: she is casual sexually, and she thought Jews had horns. But the New Yorker raises her consciousness (i.e., induces her to accept feminism), and the two succeed in establishing the union. Small town prejudices may be formidable, but strong individuals working for a great cause can overcome them.

If the '70s were a bad time for reel small towns, however, they were a pretty good time for real small towns, which surprised demographers by growing more rapidly than metropolitan areas (Fuguitt 1985). In contrast to the movies' assumption, more people moved to small towns from metropolitan areas than the reverse, whether for economic 
(e.g., Petrulis 1979) or for other (e.g., Zuiches 1970) reasons. Reports of the death of the small town were exaggerated.

The revival of small towns, however, little interested Hollywood. An occasional movie, like Hoosiers (1986), might strike a positive note, but even the hugely popular Back to the Future (1985) and its sequel (1989), though they portrayed small towns with great affection, located their prime in the good old days. Back to the Future, which uses the trite device of time travel in very innovative ways, follows the adventures of Marty McFly, an underachieving high school student in a terminally boring ' 80 s suburb who is transported back to 1955, when the suburb was a small town. He encounters his future parents, and is able to manipulate events so that when he returns to the ' $80 \mathrm{~s}$, his father and mother are not the poor, beaten down souls he knew, but instead a prosperous and happy couple. The '50s small town is full of stock characters - a bullying jock, a stern principal, a wild-haired scientist - but the small town seems little more than the setting for the story. Still, locating the town in the past - as with The Music Man, Elmer Gantry, To Kill a Mockingbird, Kings Row, and The Magnificent Ambersons - lends a mythological sheen to the tale and its theme.

As time passed, more attention was generated by the bizarre. David Lynch's Blue Velvet (1986), for instance, opens with a sequence establishing a small town idyll: blue skies, red roses, and white picket fences. Then a man collapses while watering his lawn, his dog continuing to drink from the hose. The spooky imagery continues, as the camera burrows into the green lawn and finds hungry insects beneath - a metaphor for the surface and buried lives of the town. Strains of Bobby Vinton's "Blue Velvet" fill the air, firemen wave a friendly hello, school guards help children cross the street - all reminiscent of the comforting small town hominess clichéd in the Andy Hardy and Henry Aldrich movies of the Depression. But Lynch's Lumberton, North Carolina (which "knows how much wood a woodchuck chucks") is, as the main character observes, "a strange world" that includes kidnapping, seduction, mutilation, sexual bondage, and sadomasochism. The only peaceful and cooperative community in evidence consists of ants - and they are dragging a severed human ear.

The mid-1990s saw the release of the enormously popular Forrest Gump (1994), which followed a sweet, innocent, decent boy from his home in Greenbow, Alabama to various points around the world. The hook was that Forrest was moderately retarded. Could a person of such obvious vulnerability and limitations survive and thrive in a dog-eatdog world? In the movies, where many of the characters he encounters somehow fail to notice his problem, the answer is yes. Forrest prospers, suggesting that small town values are not only morally sound, but a good basis for making money.

Tom Hanks' Forrest Gump illustrates the proposition that movie depictions of small towns, when positive, have tended to rely heavily upon the aura of the starring actors. As the personifications of plain speaking decency, Gary Cooper (Mr. Deeds Goes to Washington), Gregory Peck (To Kill a Mockingbird), Sally Field (Norma Rae), or "America's favorite feller," James Stewart (It's a Wonderful Life) could be counted on to lend authenticity to the films. (Similarly, the wholesomeness of the small town setting powerfully reinforced the actors' identification with rectitude and common sense.) Where small towns were portrayed negatively, on the other hand, the movies ordinarily lacked such iconic stars, relying on character actors like Robert Cummings (Kings Row), Arthur Kennedy (Peyton Place), or Rod Steiger (In the Heat of the Night). 

"70s theme of the town as a sad place that time had passed by. The Sweet Hereafter (1997), set in a remote Adirondack town and based on a Russell Banks novel, reveals the terrible effects of a school bus accident that takes the lives of many local children. Some personal ties are strengthened, others are weakened or even severed; the community's capacity to heal its members is sometimes real but always limited. Affliction (1998), also drawn from a Banks novel, and Joe the King (1999) each tell of dysfunctional families, full of shame and rage, in dreary towns. The highly praised You Can Count on Me (2000), set in an upstate New York town, features a sister and brother separated for some years. She, a loan officer at the tiny local bank and the single mother of a young boy, is stable, nurturing, but vulnerable to men she feels sorry for; he is a catalogue of ne'er-do-well foibles and flaws ("I'm not the kind of guy everyone says I am," he protests - but he is). The town suits her purposes fairly well, but he is simply too different from the locals ever to fit in.

61 That small towns are inhospitable to free spirits was the point of Anywhere but Here (1999) and Tumbleweed (1999), both telling of kookie mothers with adolescent daughters who flee small towns in search of fun, love and adventure. Staying put, one mother declares, would mean that her daughter would grow up to be "a nothing girl in a nothing town." Similarly, the cliché driven Varsity Blues (1999) depicts the struggles of an academically serious football player in a football worshipping small Texas town. The townsfolk's fanatical devotion, driven by a hunger for distractions, not only unites the residents but also trumps all other concerns, blotting out the entire outside world. The shallowness of small town life seems to make for shallow small town citizens. Serious individuals feel out of place.

he problem of nonconformity was still more pronounced in Boys Don't Cry (1999), for which the star won an Academy Award. Teena Brandon leaves her home town, Lincoln, Nebraska, for a small town, Falls City, and a new start in life. But the new start is far more radical than anything imagined in Anywhere but Here or Tumbleweed, for Teena Brandon decides to become Brandon Teena, and passes herself off as a boy. Reckless, she takes up with a violent, trashy crowd, and seduces one of them as her girl friend. The clear eyed vision of the small town underclass generates a powerful sense of foreboding: how long can Teena maintain the pretense and what horrible retribution will she suffer? The foreboding becomes prophecy. Teena is found out with grisly consequences. Still, the viewer wonders whether her problem was less locale than class. Had she fallen in with an underclass anywhere, even in blasé New York, she also might well have been doomed (recall Last Exit to Brooklyn [1989]); on the other hand, a kinder, more open minded crowd might have accepted her or at least done nothing worse than walk away. Consider, for example, In and Out (1997), a comedy about a popular high school teacher in Greenleaf, Indiana, whose homosexuality is revealed in a grateful former student's Academy Award acceptance speech. After a period of initial shock and confusion - the teacher himself had been in denial - the small town embraces the teacher. Unlike in Boys Don't Cry, In and Out features a town that is overwhelmingly middle class.

63 The tension between appearance and reality also runs through A History of Violence (2005). Tom Stall, modest and friendly in a reserved way, runs a diner in Millbrook, Indiana. When armed robbers terrorize his diner, he astonishes Millbrook by overpowering and killing them in spectacular leaping-and-shooting fashion, and, hailed 
as a hero, is acclaimed by the national media. This attention draws a limousine full of mobsters to Millbrook, led by one Fogarty, and we later learn that Tom himself is a reformed mobster, who must battle Fogarty and kill his own mob boss brother. Emotionally spent, Tom hurries back to the bosom of his family. In the end, though, they offer him only a tense and ambivalent welcome.

Nothing is as it seems. Tom is less Gary Cooper than Charles Bronson. His family's unconditional love is to some degree conditional on Tom's being Tom. Millbrook, with its leafy streets and Friday night high school football, is not as tranquil as the trite image would imply: Tom's son is harassed by bullies at school, his daughter imagines monsters under her bed, television news is preoccupied with crime, psychopaths take over the diner. Evil invades Millbrook, it is true, but it was never entirely evil-free, either. Indeed, the good people of the town seem mesmerized by Tom's virtuoso violence, much as the movie audience is supposed to be. Does the closing scene show Tom's family trying to come to terms with his violence and deception - or are they also distressed by learning of their own appetite for violence and deception? Even sleepy Millbrook cannot escape the cruelty and anger that mar the human condition.

Plainly, the most popular recent small town film is The Simpsons Movie (2007), set in Springfield, which one character locates as on the border of Ohio, Nevada, Maine, and Kentucky. To avoid becoming bacon, a pig flees Krusty Burger and is taken home by Homer Simpson. In only two days, its merde (and Homer's) fills a silo; Homer dumps the mess into the lake, horribly polluting all of Springfield; and the President seals off Springfield with a giant dome. The Simpsons escape to Alaska, but, learning that the President has decided to transform Springfield into a gorge resembling the Grand Canyon, Homer hastens back to the town. Its residents, he finds, have nearly destroyed it, but Homer succeeds in blowing up the dome, freeing the people, who then rebuild the town.

The movie, a mad, animated satire made with steroidal brio, makes fun of everything, from stale targets like government to fresh ones like environmentalism. The traditional attachment of small town folks to their perfectly ordinary and undistinguished town is mocked repeatedly. Yet the film machineguns so many objects that it is not clear how small town-centered it really is, for it is easy to imagine a similar movie set in a suburb or even (with a few strategic alterations) in a metropolis.

67 A much more traditional small town comprises the setting for Tyler Perry's Meet the Browns (2008). An African American single mother with three children by three men unexpectedly loses her job in Chicago, learns of the death of a father she never knew, and, desperate, brings her family to the small town Georgia funeral. There she meets her relatives, the Browns, inherits a run down house, and connects with a hunky college basketball recruiter trying to snare her son. The contrast to big city life could hardly be plainer, as the pace of life slows radically in a mélange of lazy afternoons and corny county fairs. All life's problems do not disappear - fathers abandoning their children, after all, is the fulcrum of the plot - but they can be managed satisfactorily in small town America. Not the least interesting aspect of this film, which, like Perry's previous films was enormously popular with African American audiences, is that good things happen to black characters, when they move from Chicago to Georgia. It was not long ago when such a scenario would have been dismissed as preposterous.

There are other signs that the old sentimental appeal of small town life has retained at least some of its vigor. Real estate developers, for example, have devised an upscale 
niche product they call New Ruralism, featuring new communities (often named "settlements") with the look of 19th, 18th, or even 17th century small towns (Lewis 2008). Whether this represents a flight from the soulless metropolis to the fuzzy embrace of slicked up nostalgia is hard to say. But when a French film, Bienvenue Chez les Ch'tis (2008), a low budget celebration of the quirky kindness of residents of a decidedly unpicturesque petit ville, sets records for ticket sales, it is plain that the phenomenon is not restricted to the United States.

\section{CODA} independence has an uncanny application to the situation of small towns. At one pole, a fully independent town would be entirely autonomous, determining its own destiny for its own reasons. A fully dependent town, at the opposite pole, would be utterly at the mercy of outside forces and decision makers. Nearly all towns fall between these two ideal types, their precise position in continual flux in response to pushes and pulls from both directions.

70 For a long time, really until the 1950s, movies portrayed small towns as more or less self contained little worlds of their own. There were few references to the outside world - particularly, to Washington or to foreign countries - even when war or depression made interconnectedness obvious and indisputable. But it was not only political or economic ties that were ignored. Social or cultural ties were also passed over.

With the postwar era, the independence of the small town began to be questioned, and by the 1960s itself became a theme to explore. The Music Man saw the isolation of small towns as rendering them vulnerable to unscrupulous manipulation; the isolation of the small town in In the Heat of the Night required intervention by a despised outsider; the recognition that the small town was a tiny and dispensable cog in a much larger machine led young people in The Last Picture Show and American Graffiti to decide to leave to seek their fortunes elsewhere; even in Blue Velvet, where the small town's independence is flaunted, it is not expressed in the old virtues but rather is mocked as bizarre. Thus, though the postwar era surely has had call for havens from storms, movies have no longer sited these havens in small towns.

Television, however, did - for a while. Andy of Mayberry, The Waltons, Life Goes On, and Northern Exposure each invited us to escape to a self-contained town, where folks are friendly and decent, and the strains of the larger society can be laid aside. Problems exist and sometimes they are serious. But the problems are personal and, if not solvable, at least manageable when addressed with common sense and good will. Advertising campaigns, on television but also in magazines and the Internet and on billboards, have also proclaimed the wholesomeness of small towns over and over and over again. Still more upbeat, Walt Disney's fabulously successful theme parks are anchored by super-tidy reproductions of century-old Main Streets - modeled after Marceline, Missouri's Main Street, where Disney spent a few idyllically youthful years that introduce visitors to their wondrous surroundings.

If Disney idealized the small town in a seductive commercial parody of a Platonic archetype, he surely targeted the heart of its appeal: its ordinariness. The small town of the popular imagination is without leftist intellectuals, restaurants that foam zucchini,

European journal of American studies, 6-1 | 2011 
and nude performance artists. There may be oddities - the concrete statues of Paul Bunyan and Babe the Blue Ox in Bemidiji, MN or Beaver, OK proclaiming itself the capital of cow chips - but these are done in the spirit of fun, are not subversive, and threaten nothing. Celebrating ordinariness may seem an oxymoron - we assume we celebrate the extraordinary - or at least superfluous - why encourage what already exists in abundance? Its appeal, however, is not hard to see. For celebrating ordinariness celebrates the audience, who may think of themselves as unique but not really special, like a fingerprint. Moreover, celebrating ordinariness merges effortlessly into celebrating democracy, which in common speech is typically described as government by the people. Small town films are only rarely about residents who left and became rich or famous. Instead, they typically focus on ordinary people living ordinary lives.

The wholesome ordinariness also embodies a pervasive sincerity, a defenseless absence of the artifice that is thought to permeate human relations in big cities. In place of cynicism or hipper-than-thou attitude is an openness that nostalgically recalls an imagined bygone time of innocence. As the larger society has become increasingly distanced from this supposed era, its salience has markedly decreased. Indeed, the major studios have retreated from a concern with human relations in favor of outright fantasies, computer generated special effects, superheroes borrowed from comics, animated creatures, and gross-out adolescents. The small town has not secured a role in this brave new world.

If the small town of the imagination retains some of its venerable appeal, however, real small towns have long had a case of the dwindles. The reasons are obvious: small towns, whatever their perceived advantages, simply are not seen as offering the economic and social opportunities of metropolitan areas. It is not only that as the number of small towners has declined, so, too, has the movies' interest in them. Small towns no longer constitute a substantial potential audience. It is also that the popular image of the small town has evolved from a prosperous, friendly refuge to a place beset by problems, especially economic problems. Bustling Main Street has been replaced by boarded up shop windows, and parades, music at a band stand, and sandlot baseball all seem the subjects of grandpa's snapshots. Even in an era of interminable bloviating on the virtues of family values, the image of the small town, for so long the keeper of these values, fades in a quiet diminuendo. Today's movie goers, overwhelmingly young and from metropolitan areas, conceive small towns as inhabited by remote, dull tribes best forgotten, leaving moviemakers little reason to focus on them. On television, too, programs normally focus on a glamorized urban life - Seinfeld, ER, Sex and the City, suburban reality shows -- and once popular small town shows have largely been relegated to reruns on niche cable channels. The small town is certainly not dead. But the small town movie appears to be in eclipse. It is very doubtful that it will soon recover. 


\section{BIBLIOGRAPHY}

WORKS CITED.

Anderson, Sherwood. Winesburg, Ohio. New York: Modern Library, 1919.

---. Puzzled America. Mamaroneck, NY: P.P. Appel, 1935.

Basinger, Jeanine. The It's a Wonderful World Book. New York: Knopf, 2004.

Brace, Charles Loring. The Dangerous Classes of New York and Twenty Years Working among Them. New York: Wykoop and Hallenback, 1872.

Bryan, William Jennings. Speeches. New York: Funk \& Wagnalls, 1909.

Christopher, Nicholas. Somewhere in the Night. New York: Free Press, 1997.

Doherty, Thomas. Pre-Code Hollywood. New York: Columbia University Press.

Dreiser, Theodore. An American Tragedy. New York: Boni and Liveright, 1925.

Fischer, Claude S. The Urban Experience. 2d ed. San Diego: Harcourt Brace Jovanovich, 1984.

---. "The Public and Private Worlds of City Life." American Sociological Review. 46 (1981): 306-16.

Fitzgerald, F. Scott. The Last Tycoon. New York: Scribners, 1941.

Flagg, Fannie. Standing in the Rainbow. New York: Random House, 2002.

Fuguitt, Glen V. "The Nonmetropolitan Population in Turnaround." Annual Review of Sociology. 11 (1985): 259-80.

Gabler, Neil. Life the Movie. New York: Knopf, 1998.

Garland, Hamlin. Main Travelled Roads. New York: Harper, 1899.

Goldsmith, Oliver. The Deserted Village, the Traveller, and Other Poems. Boston: Houghton, Mifflin, 1894/1770.

Griffith, Richard. Mayer, Arthur, and Bowser, Eileen. The Movies. Rev. ed. New York: Simon and Schuster, 1981.

Howell, William Dean. A Modern Instance. Cambridge: Riverside Press, 1923.

Inge, William. Picnic. New York: Random House, 1953.

Jefferson, Thomas. Works. Ed. P.L. Ford. New York: Appleton, 1904.

Just, Ward. Rodin's Debutante. Boston: Houghton Mifflin Harcourt, 2011.

Korte, Charles. "Helpfulness in the Urban Environment." Advances in Environmental Psychology. Eds. Andrew Baum et al. Volume I. Hillsdale, NJ: Earlbaum, 1978.

Kracauer, Siegfried. From Caligari to Hitler. Princeton University Press, 1947.

Lee, Harper. To Kill a Mockingbird. Philadelphia: Lippincott, 1960.

Lewis, Christina. "Selling History by the Square Foot." Wall Street Journal. 4 April, 2008: W8, col. 2. Lewis, Sinclair. Babbitt. New York: Harcourt, Brace, 1922.

---. Elmer Gantry. New York: Harcourt, Brace, 1927.

---.Main Street. New York: Harcourt, Brace, 1920. 
Lofland, Lyn H. A World of Strangers. New York: Basic, 1973.

Lynd, Robert S. and Lynd, Helen M. Middletown. New York: Harcourt, Brace, 1929.

---. Middletown in Transition. New York: Harcourt, Brace, 1937.

Lyford, Joseph P. The Talk in Vandelia. New York: Harper and Row, 1964.

Marquand, John P. The Point of No Return. Boston: Little, Brown, 1949.

Masters, Edgar Lee. Spoon River Anthology. New York: Macmillan, 1915.

Mayer, Arthur and Bowser, Eileen. The Movies. Rev. ed. New York: Simon and Schuster.

McCullers, Carson. A Member of the Wedding. Boston: Houghton, Mifflin, 1946.

Metalious, Grace. Peyton Place. New York: Messner, 1956.

O'Nan, Stewart. Last Night at the Lobster. New York: Viking, 2007.

Petrulis, Mindy F. “Growth Patterns in Nonmetropolitan Manufacturing Employment." USDA

Rural Development Research Report No. 7. (1979).

Potter, David M. “The Enigma of the South.” Yale Review. 51 (Autumn 1961): 143-51.

Sanders, James. Celluloid Skyline. New York: Knopf, 2001.

Simmel, Georg. "The Metropolis and Mental Life.” The Sociology of Georg Simmel. Ed. Kurt Wolff. Glencoe: Free Press, 1950, 409-24.

Tarkington, Booth. Alice Adams. New York: Grosset and Dunlap, 1921.

---.The Magnificent Ambersons. Garden City: Doubleday, Page, 1918.

Weber, Max. The City. Ed. and trans. Don Martindale and Gertrude Neuwirth. Glencoe: Free Press, 1958.

Weibe, Robert H. The Search for Order. New York: Hill and Wang, 1967.

Wirth, Louis. “Urbanism as a Way of Life.” American Journal of Sociology. 44 (1938): 3-24.

Wolfenstein, Martha and Leites, Nathan. Movies. Glencoe: Free Press, 1950.

Zuiches, James J. “Immigration and Growth in Nonmetro Urban Places.” Rural Sociology. 43 (1970): 410-20.

\section{NOTES}

1. Louis Wirth, in his classic essay, "Urbanism as a Way of Life," found the city to be "characterized by .. . impersonal, superficial, transitory, and segmental [relationships]. The reserve, the indifference, and the blasé outlook which urbanites manifest in their relationships may thus be regarded as devices for immunizing themselves against the personal claims and expectations of others" (Wirth 12; see also Guterman).

2. Lofland and Fischer report that though city residents tend to be indifferent to unfamiliar or socially dissimilar people and less attracted to formal organizations (like churches), they are far from anomic, estranged individuals, alienated from their fellows. Fischer, in particular, argues that cities' "interconnected social networks," or subcultures, permit individuals to form significant ties with people like themselves, resulting in relationships as rich and meaningful as those enjoyed by small town residents (Fischer 297, n. 26). 


\section{ABSTRACTS}

As America thinks about itself - its values, its roots, its evolution - a central theme is the small town, cherished as a wholesome refuge, warm and friendly, and derided as dull and provincial, intrusive and nosy. From their inception, movies have served as one of the society's principal means of discourse on the topic, generally lauding small towns during the silent era and the Depression, becoming steadily more critical after the war, and more recently depicting them as faded anachronisms. The reel small town is compared to the real small town, and Simmel's notion of the plight of the individual in modern society provides an organizing principle.

\section{AUTHOR}

THOMAS HALPER- DOUGLAS MUZZIO

Baruch College, CUNY and Douglas Muzzio, Baruch College, CUNY 